\title{
Study on Physical Training in Colleges and Universities with a Combination of Computer-aided Analysis
}

\author{
Lin Xiaoming \\ Zhonghuan Information College Tianjin University of Technology, Tianjin Xiqing 300380 China
}

Keywords: auxiliary teaching, application, computer, college physical training

\begin{abstract}
Along with the development of computer network technology and Internet, network courses have become an irreversible trend. When sports dance be displayed in a network platform, it can both benefit the classroom teaching and extracurricular self-study. This research combined the literatures research and experimental research, and demonstrated the advantages of the application of network courses for auxiliary teaching in sports dance.
\end{abstract}

\section{Introduction}

With the rapid development of science and technology and deepening the reform of training, multimedia computer technology as a means of modern teaching, training, has been in practical teaching in all disciplines have a wide range of applications[1], and played an important role, has made great achievements. Multi - media teaching learning and training is the use of courseware, on the basis of the text, combined with images, sounds, animations, and other means, Caused by various methods of teaching and training of students' interest[2]. Teaching, training courseware model applied to the foot in teaching will challenge the traditional pattern of a single football teaching, and future developments Trend. College football as a discipline should also be recognized [3-4].

\section{Subjects and Methods}

Random Information Engineering College of Shandong University Weihai at the 2006 level football for teaching subjects, 4 natural class of 120 students divided into groups A and B ( all for 2 classes ), $\mathrm{A}$ is the control group, $\mathrm{B}$ is the experimental group. In the case of experimental teaching the same content, compared with a traditional Teaching methods, use the experimental group B " class video " with a combination of multimedia courseware Teaching, and have their comparative study on the effect of teaching. In experiment examination, in order to ensure experimental conditions Consistency, experimental class and a class taught by 1 teachers were, at the same time to avoid people For the subjective assessment of factors, on the Teaching Evaluation using quantitative criteria, with a view to an objective and true Reflection of Teaching law. Technical examination grade point average is showed Table 1.

Tab.1 Technical examination grade point average $n=120$

\begin{tabular}{|c|c|c|c|c|c|c|}
\hline Group & catch ball & Volleys & shot & dribble & Placement & average \\
\hline $\begin{array}{c}\text { The } \\
\text { control } \\
\text { group A }\end{array}$ & 64.5 & 71.5 & 68.5 & 70.2 & 63.2 & 67.58 \\
\hline $\begin{array}{c}\text { The } \\
\text { control } \\
\text { group B }\end{array}$ & 74 & 72.5 & 74 & 75 & 68 & 72.7 \\
\hline
\end{tabular}

\section{Results of Questionnaire}

Through recycling statistics and arrangement of the questionnaire, the situation in table 2, 100 of 
the students agree with the attitude of Multimedia Teaching, 96.3 of students think more conducive to more traditional teaching of Multimedia Teaching for mastery of knowledge, worth promoting.

Tab.2 Students' understanding of the kinds of teaching degree $n=120$

\begin{tabular}{|c|c|c|}
\hline Items & population & Percentage (\%) \\
\hline $\begin{array}{c}\text { Whether to increase interest } \\
\text { in learning }\end{array}$ & 117 & 97.5 \\
\hline $\begin{array}{c}\text { Whether to raise the } \\
\text { understanding of } \\
\text { knowledge }\end{array}$ & 115 & 98.8 \\
\hline $\begin{array}{c}\text { Is beneficial to the focus of } \\
\text { attention }\end{array}$ & 118 & 95 \\
\hline $\begin{array}{c}\text { Is beneficial to the grasp of } \\
\text { knowledge }\end{array}$ & 120 & 100 \\
\hline $\begin{array}{c}\text { Agree on the Multimedia } \\
\text { Teaching degree }\end{array}$ & 116 & 96.7 \\
\hline Teaching satisfaction & 114 & 98.3 \\
\hline
\end{tabular}

Limitations of traditional teaching : As I grow older, some of the decline of Physical Quality of physical training teachers, coupled with the usual transactional a lot of things, less time for exercise, weight gain, some of the tougher action to complete the action model, does not work effectively or complete, affecting the teaching effect. If you have a combination of video multimedia assisted instruction courseware, you can make up for deficiencies in physical training teaching.

\section{Teaching Conclusions}

Multimedia courseware to provide students with a complete knowledge of detail, rich pictures and videos to help students be more, faster, better and more economical to grasp the knowledge and skills of physical exercise, intuitive, easy to understand and master, to improve the knowledge mastery. Students can compare video data and multimedia courseware, self-counseling, teaching beyond the limits of time and space, interact with the computer to achieve the purpose of self-study, which greatly improves the efficiency of teaching.

Made of multimedia courseware, graphics and appearance, is a sign of modernization of teaching. Training Teaching develop without the means to update and progress and multimedia aided teaching is a product of the development of information technology, with the progress of the times, the pace of modernization of training should also be keeping up with the times, the replacement of the implementation of teaching methods.

\section{Computer-aided Teaching of Physical Training on the Proposal}

National and school authorities at all levels should strengthen the construction of Multimedia Teaching of hardware facilities, adequate emphasis on the role of multimedia technology in the teaching of physical training, increase investment, establish and improve the Multimedia Teaching of multimedia - aided teaching software system and network environment.

Recommended for multimedia training of PE teachers in colleges and universities should increase its technical training, practical in place of the popular multimedia and network - aided teaching plan, organization of computer professionals, systematic training of physical training teachers. The general physical training teachers update their concepts, advanced multimedia teaching method and means of continuous learning, give full play to the computer age to the basic requirement for teachers of physical training, physical training teachers is an important condition for the future is capable of teaching. 


\section{Research Results and Analysis}

Random subjects are divided into 80 before the experiment experimental class (40) and control classes (40). Comparative physical training classes using the traditional method in the experiment; experimental class in traditional physical training on the basis of the law, the application of network curriculum for secondary training. After the experiment the two mixed and performance assessment, and therefore the data comparison and analysis of the results. The results as shown in table 3 , table 4.

Tab.3 After the experiment comparison of students' sports action completed results table

\begin{tabular}{|c|c|c|c|c|c|c|}
\hline Group & $\mathrm{N}$ & $\begin{array}{c}\text { Excellent } \\
(90-100)\end{array}$ & $\begin{array}{c}\text { Well } \\
(79-89)\end{array}$ & $\begin{array}{c}\text { pass a test } \\
(60-78)\end{array}$ & $\begin{array}{c}\text { Fail } \\
\text { (below } \\
60)\end{array}$ & $\begin{array}{c}\text { Average } \\
\text { Mean }\end{array}$ \\
\hline Control class & 40 & $\begin{array}{c}4 \\
10 \%\end{array}$ & $\begin{array}{c}20 \\
50 \%\end{array}$ & $\begin{array}{c}16 \\
40 \%\end{array}$ & 0 & 82.4512 \\
\hline $\begin{array}{c}\text { Experiment } \\
\text { class }\end{array}$ & 40 & $\begin{array}{c}13 \\
32.5 \%\end{array}$ & $\begin{array}{c}25 \\
62.5 \%\end{array}$ & $\begin{array}{c}2 \\
5 \%\end{array}$ & 0 & 86.3654 \\
\hline
\end{tabular}

Table 3 is a percentage of average and class against class 82.4512 , the best percentage (10\%), experimental class 86.3654, the best percentage (32.5\%). Experimental Class clearly higher than the Control class.

Tab.4 Action completed score variance of physical training after the experiment results

\begin{tabular}{|c|c|c|c|c|c|}
\hline & $\begin{array}{c}\text { Sum of } \\
\text { Squares }\end{array}$ & df & $\begin{array}{c}\text { Mean } \\
\text { Square }\end{array}$ & F value & P value \\
\hline Between-group & 235.653 & 1 & 235.624 & 6.324 & 0.0243 \\
\hline Within-group & 2959.697 & 77 & 38.264 & & \\
\hline total variance & 3254.2340 & 80 & & & \\
\hline
\end{tabular}

Because the traditional process of physical training teachers and students in Class exchanges less, some students as class people more or less and cannot fully grasp the technique, but there is no reference for practicing again after you have a class at a time can only be learned by half, piling up over and over again will not be solved, leading them to lose confidence, and less interest in learning, even skip school - weariness of the phenomenon. And the network as a secondary application in the teaching of Sports Dance Teaching of the course can not only allow students in the Class View in visual multimedia information, you can also let the students after class in the course of teaching video over the network to consolidate in class is not fully available.

\section{Summary}

At present, because on the market meets physical training, to meet the teachers don't have much to explain the content of Multimedia Courseware of football, physical training teachers should work together with the development of courseware for computer professionals, borne by the gym teacher Design of Courseware script, use a computer professional Multimedia Courseware of physical training teachers or teacher technology, relying on the strength of the team developed a high quality, for practical teaching of multimedia courseware. The proposed sports workers widely listened to the views of students, collection, sorting and video footage material of interest to some students, the feasibility of metaphor teaching at the full impact of teaching.

\section{References}

[1] Z.W. Gong: Reform and Development of School Sports (Beijing Sports University Press, China 2010). 
[2] D.P. Li: Sports world, Vol. 4 (2009), p.25.

[3] H.F. Li: Neijiang science and technology, Vol. 11 (2007), p.31.

[4] J.L. Gao: Modern Education technology and modern education (Guangxi Normal University Press, China 2011). 